\title{
短繊維混合補強土における補強材 混合量の影響
}

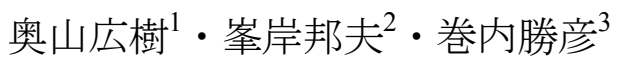

\begin{abstract}
短䋊維混合補強土工法は，短繊維を摚拌・混合寸ることにより，地盤材料に高付加価値化を 行い，新しい地盤性状の特性を付与し，より優れた地盤材料を作り出寸補強土技術である。し かしながら，補強メカニズムについては十分に解明されていないため，実験的研究の実績を積 み重㸚ると供に，その結果を理論的に結びつけることが必要である。

そこで, 本研究では, 関東ロームを試料土として, 短繊維補強材の種類や配合量の変化が, 補 強メカニズムに及ぼす影響を調べるため, 寸法の異なる供試体を用い試験を行い，これらの試験 結果について考察し，主に供試体の寸法効果や短繊維の最適混合量に言及した。
\end{abstract}

キーワード : 補強土，短繊維，建設発生土

\section{1.はじめに}

土木構造物を構築する場合, その安定性を確保す るために盛土体や切土斜面の強度, 地盤支持力の増 強を図らなければならない場合がある。その方法と して, 土（盛土，地山，地盤）の中に土よりも高剛 性, 高強度の補強材を敷設あるいは挿入し, 土と補 強材との相互作用によって地盤の変形を内部から拘 束し，土塊全体の安定性や強度を高める工法がある。

その一つに, 地盤材料の補強材として短繊維を混 入する補強土工法がある。この工法は短纎維混合補 強土工法と呼ばれており, 今までの補強土工法と異 なり, 地盤材料に補強材である繊維を土中に均一に 分散させ，三次元的に配置する補強形態である 1)。 この方法の力学的な補強メカニズムは, 混合するこ とにより繊維と土が絡み合い，本来土が弱いとされ る性質である引張力に対する抵抗を高め, せん断時 には土粒子の移動を補強材によって拘束し，外力に 対する抵抗性が付加されることにある。また，纎維 混合補強土工法は, 「補強土としての機能」だけで なく，緑化などの建設によって失われつつある自然 環境や景観を「復元寸る技術」として，今後の発展 に期待されている工法である。一方，公共工事にお いても, コスト縮減等の観点より設計の段階から切 土, 盛土のバランスを工夫する等, 建設発生土の現 場内利用が推奨されている ${ }^{2)}$

しかし, 短繊維混合補強土は, 本来, 粘着力の少 ない砂質土に䋊維を混合することで強度増加ととも に粘着性が上がることが明らかになっているが，粘 性土を対象にした研究例は少なく, 既往の研究で短
繊維混合補強土の補強効果については明らかにされ ているが，短繊維の最適混合量と短繊維を混合した 供試体の寸法効果についてはまだ未解明な部分が多 い。

そこで，本研究では関東近郊での施工を想定し， 関東ロームを用いた短繊維混合補強土に対する補強 材の最適混合量と供試体の寸法効果について一軸圧 縮試験結果より評価した。次に, これらのデータを 基に交通施設（道路盛土）への応用を考え，圧密非 排水三軸圧縮試験の結果を用いてモデル斜面の安定 解析を行い，短繊維混合による補強効果の考察を行 った。

\section{2. 使用材料}

本研究では, 試料土として関東ローム, 補強材と して今回の実験では，米国フォルタ社のコンクリー ト・モルタル用補強繊維ウルトラネットを使用した。 この短繊維はポリプロピレンによるネットワークフ アイバーで，通常の補強用繊維と異なりポリプロピ レン繊維をネット状に加工したものである。繊維長 の異なる 2 種類のポリプロピレン製の短繊維 A（長 さ $2 \mathrm{~cm}$ ），短繊維 $\mathrm{B}$ （長さ $5 \mathrm{~cm}$ ）を用いた。特長と しては，以下のことが挙げられる。なお，短繊維の 形状と特性 ${ }^{3)}$ を以下および表ー 1 に示す。

(1) 高強度で引張りに強く, 軽い。

(2) 耐薬品性である。

(3) 無機物のため微生物によって分解されず，半 永久的に補強可能である。

\footnotetext{
1正会員, 日本大学理工学部 社会交通工学科, 助手（テ274-8501千葉県船橋市習志野台7-24-1）

個人会員，同上，准教授

3個人会員, 日本大学名誉教授
} 


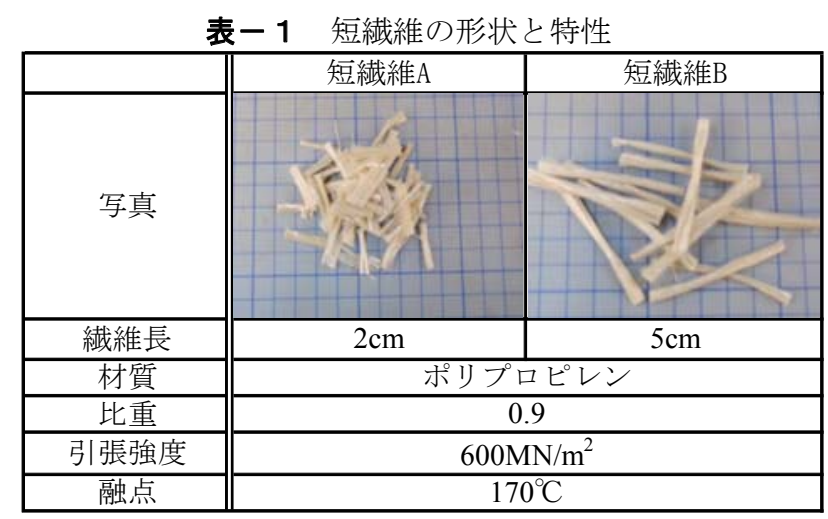

また, 試料の関東ロームは日本大学理工学部二和 校地（千葉県船橋市，図ー1）で採取したものを 2 $\mathrm{mm}$ ふるいにかけ，その後，含水比が $90 \%$ 程度にな るまで室内乾燥したものを用いた。これは，試料を 均質に保ち混合しやすくすることや実験データのば らつきを抑えるためである。ふるい分け後の関東口 一ムの性質を表一 2 に示す。関東口ームの基本的性 質として，構成粒子は微細な結晶や風化粘性土化し た火山ガラスやその他の風化生成物が結合して，単 結とも，団結とも区別できないものや，単粒として 粒径が明確でないものが含まれている。間隙比が非 常に大きく, 間隙率で表すと 75〜80\%である。含水 比も高く，一般に 80〜 180\%の範囲でありばらつき が多い，しかし，含水量そのものが大きいというわ けではなく，非自由水含有量がきわめて多いとされ， 他の工学的性質との関連の上で重要となる。また土 粒子の密度は大きいが, 含水比, 間隙比が大きいの で単位体積重量は小さい值を示し， $1.3 \sim 1.4 \mathrm{~g} / \mathrm{cm}^{3}$ 程度の值となり，乾燥した場合の密度は $0.6 \sim 0.7$ $\mathrm{g} / \mathrm{cm}^{3}$ 程度となり，非常に小さい值を示すことが特 徵である ${ }^{4)}$ 。また，機械の施工作業によってこね返 し受けると著しく軟弱化してしまい，施工機械のト ラフィカビリティーが低下する特徵がある。

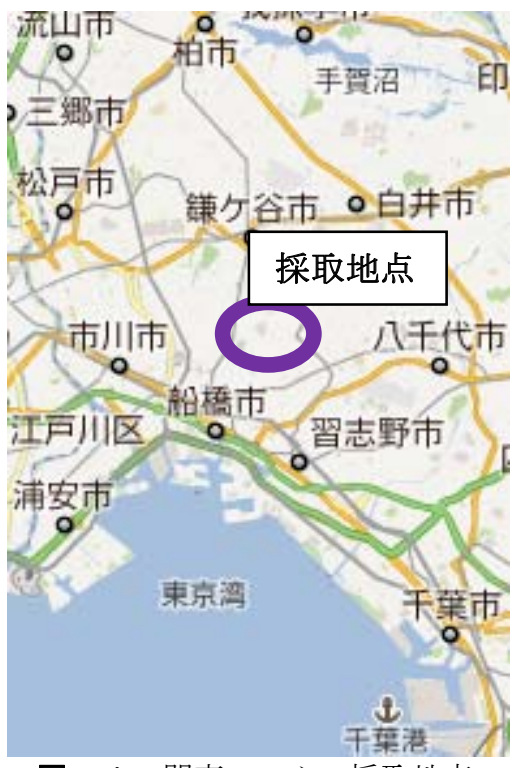

図ー 1 関東ロームの採取地点 (google マップから引用)
表－2 関東ロームの一般的性質

\begin{tabular}{|c|c|}
\hline 土粒子の密度 $\rho_{\mathrm{s}}\left(\mathrm{g} / \mathrm{cm}^{3}\right)$ & 2.83 \\
\hline 夜性限界 $\mathrm{w}_{\mathrm{L}}(\%)$ & 149.2 \\
\hline 塑性限界 $\mathrm{w}_{\mathrm{p}} \quad(\%)$ & 104.8 \\
\hline 塑性指数 $\quad \mathrm{I}_{\mathrm{p}}$ & 44.4 \\
\hline 最大粒径（mm） & 2 \\
\hline $60 \%$ 粒径 $\quad \mathrm{D}_{60}(\mathrm{~mm})$ & 0.12 \\
\hline $50 \%$ 粒径 $\quad \mathrm{D}_{50}(\mathrm{~mm})$ & 0.078 \\
\hline $30 \%$ 粒径 $\quad \mathrm{D}_{30}(\mathrm{~mm})$ & 0.029 \\
\hline $10 \%$ 粒径 $\quad \mathrm{D}_{10}(\mathrm{~mm})$ & 0.003 \\
\hline 均等係数 $\mathrm{U}_{\mathrm{C}}$ & 40 \\
\hline 曲率係数 $\mathrm{U}_{\mathrm{C}}^{\prime}$ & 2.33 \\
\hline 分散剂 & $\begin{array}{c}\text { ヘキサメタりん酸ナト } \\
\text { リウム水飽和溶液 } \\
(10 \mathrm{ml}) \\
\end{array}$ \\
\hline 最大乾燥密度 $\rho_{\mathrm{dmax}}\left(\mathrm{g} / \mathrm{cm}^{3}\right)$ & 0.704 \\
\hline 最適含水比 $\quad \mathrm{w}_{\mathrm{opt}}(\%)$ & 94.5 \\
\hline
\end{tabular}

\section{3. 供試体作製方法}

一軸圧縮試験および三軸圧縮試験用供試体の作製 方法は，所定量の関東ロームおよび補強材を十分混 合後，短繊維が均等に混ざるように含水比を $100 \%$ とした加水法である。

関東ロームと短繊維を十分混合した後, $2.5 \mathrm{~kg}$ の ランマーと専用塩ビ管モールド（写真ー1）を用い て突固めにより作製した。なお，締固めエネルギー は締固め試験 a 法（JIS A 1210）を基にした。ここ で、短繊維 $\mathrm{A} ， \mathrm{~B}$ を関東ロームの乾燥質量に対する $0.5 \% \sim 0.9 \%$ の混合率で標準供試体（ $\phi: 5 \mathrm{~cm} \times$ $\mathrm{h}: 10 \mathrm{~cm})$ ，大型供試体 $(\phi: 10 \mathrm{~cm} \times \mathrm{h}: 20 \mathrm{~cm})$ を作製 した。供試体ごとの締固め回数は表ー 3 に示す。ま た，作製後の供試体を写真－ 2 に示す。

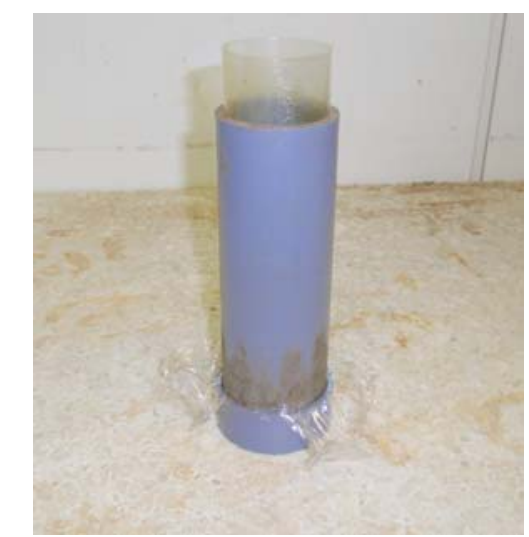

写真ー 1 塩ビ管モールド

表 -3 供試体の締固め回数

\begin{tabular}{|c|r|r|}
\hline 供試体寸法 $($ 直径 $\times$ 高さ) & 層数 & 各層締固め回数 \\
\hline \hline 標準: $5 \mathrm{~cm} \times 10 \mathrm{~cm}$ & \multirow{2}{*}{3} & 5 \\
大型 $: 10 \mathrm{~cm} \times 20 \mathrm{~cm}$ & & 39 \\
\hline
\end{tabular}




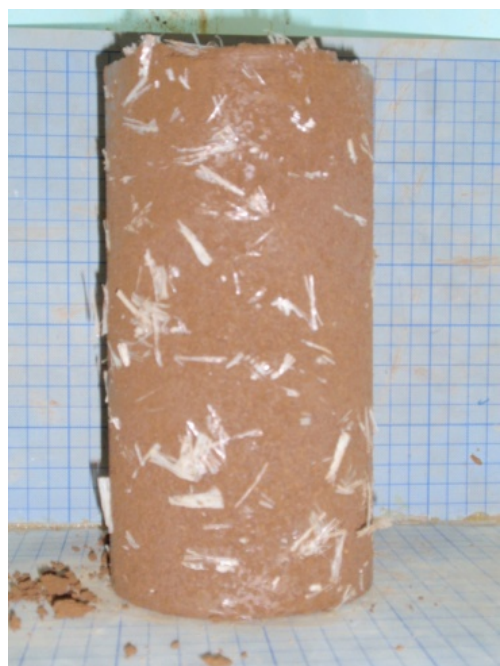

写真-2 短繊維混合の供試体

\section{4. 試験方法}

一軸圧縮試験は，短繊維の強度測定と最適混合量, 破壊状況を把握するために行った。試験は JIS A 1216 に準じて行った。

三軸圧縮試験は短繊維混合補強土の補強効果と強 度定数についてより詳しく把握するため, 圧密非排 水三軸圧縮試験（CU）を行った。CU 試験は約 24 時間かけて供試体を飽和させた後, 圧密して試験を 行った。このときのセル圧を $\sigma_{r}=20,30,50$, $100 \mathrm{kN} / \mathrm{m}^{2}$ とし JGS 0522 に準じて行った。

\section{5. 試験結果および考察}

\section{（1）一軸圧縮試験}

図ー2〜図－5は，短繊維なし，短繊維Aまたは 短繊維Bを所定の割合で混合した結果を供試体寸法 ごとに圧縮応力の関係を $\sigma-\varepsilon$ 曲線で示したもので ある。その結果, 標準供試体は短繊維を混合するこ とにより，圧縮強度が増加し補強効果が確認された。 また，これらの図より, 一軸圧縮強さ $\mathrm{q}_{\mathrm{u}}$ が発生した 後もある程度の残留強度（粘り強さ）が発現してい た。しかし，一軸圧縮強さについてみると短䋊維A 大型 $0.6 \%$ は, 短繊維を混合しないものとの差異が 明確に見られなかった。これは，供試体を作製する 際に，一つの供試体内に含まれる短繊維の量が多い と, 均一に混合されず短繊維が一部にまとまってし まい, 土との絡みが少なくなるため, 圧縮強度が増 加し得なかったと考えられる。また, 一軸圧縮強さ が最も高い值は短繊維 B標準 $0.6 \%$ の供試体だった。 短繊維Bは供試体内に短絨維が均等に配置されれば, 補強効果が高くなると考えられる。大型供試体では 全体的かつ均等に短繊維を混合することでほぼ強度 増加の傾向がみられたが，短繊維を混合しないもの より強度が低いものもあった。これは供試体を作製 する際に発生する試料土の継目部分が十分に馴染ま ず，このような結果になったと考えられる。一方，
標準供試体で強度が最も高かった短繊維 $\mathrm{B}$ 標準 $0.6 \%$ はそれど強度増加につながらなかった。その 原因としてはせん断面付近に短繊維が配置されず, 強度増加につながらなかったと考えられる。

これらの図より短繊維を混合することで残留強度 が増加し，靰性（粘り強さ）が発現することがわか った。供試体別に見ると大型供試体は標準供試体に 比べて残留強度が大きくなった。これは標準供試体 の直径が $5 \mathrm{~cm}$ に対して, 短䋊維 B は長さが $5 \mathrm{~cm}$ の ため作製時に短繊維が重なってしまい，均等に短繊 維が配置されなかったと考えられる。

また，写真一 3 に一軸圧縮試験終了後の供試体を 示す。この写真から, 供試体がせん断面付近に短繊 維が配置されていることが確認され, 架橋効果とな って残留強度が増加したと思われる ${ }^{5)}$

表 -4 表 -5 は, 一軸圧縮試験の平均強度定数 を示したものである。強度定数の求め方は式一

（1），（2）に示す。粘着力 $\mathrm{c}_{\mathrm{u}}$ については短繊 維なしと短繊維を混合したものでほぼ同じ結果にな った。これは, 関東ロームが粘性土のため, 短繊維 で粘着性を付随できなかったと考えられる。また， せん断抵抗角 $\phi_{\mathrm{u}}$ でも各配合条件で一定の傾向は見 られなかった。これは供試体内に含まれる短繊維の 混合量に多少のばらつきが生じたため, このような 結果になったと考えられる。変形係数 $\mathrm{E}_{50}$ は短繊維 を混合することで減少傾向を示した。これは，短繊 維を混合することで湿潤密度が低くなり，供試体内 部で撹乱による乱れ，不均一性が大きくなったので はないかと考えられる。

また，本研究の範囲内での短䋊維の最適混合量に ついては, 図ー6〜図ー7から短繊維A を0.7\%混合 することが最適であることがわかった。

$$
\begin{aligned}
& 45^{\circ}+\frac{\phi_{u}}{2}=\theta \\
& c_{u}=\frac{q_{u}}{2} \times \frac{1-\sin \phi_{u}}{\cos \phi_{u}} \\
& \text { ここで, } \theta: \text { すべり面角（度）, } \mathrm{q}_{\mathrm{u}}: \text { 一軸圧縮強 }
\end{aligned}
$$

さ $\left(\mathrm{kN} / \mathrm{m}^{2}\right)$ である。

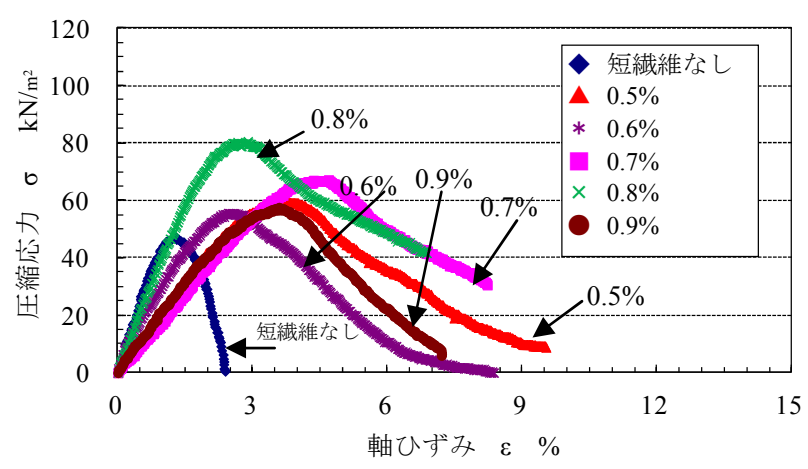

図-2 短繊維 A の混合率ごとの $\sigma-\varepsilon$ 曲線（標準供試体） 


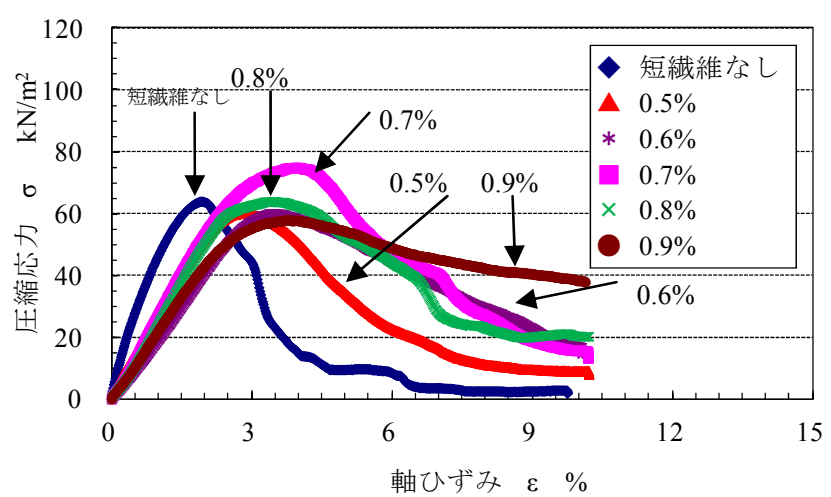

図一3 短繊維 A の混合率ごとの $\sigma-\varepsilon$ 曲線（大型供試体）

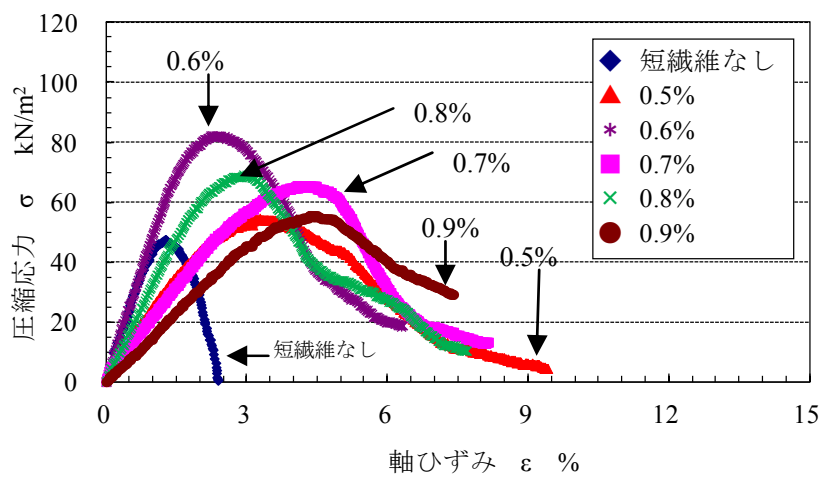

図-4 短繊維 B の混合率ごとの $\sigma-\varepsilon$ 曲線（標準供試体）

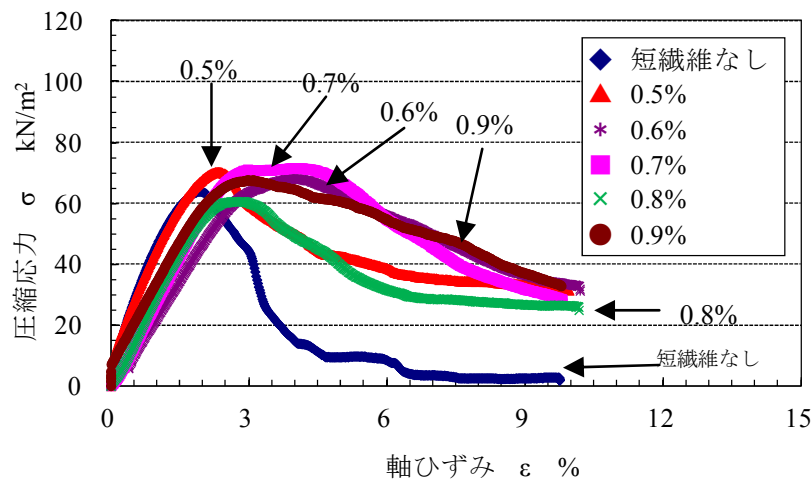

図ー5 短䋊維 B の混合率ごとの $\sigma-\varepsilon$ 曲線（大型供試体）

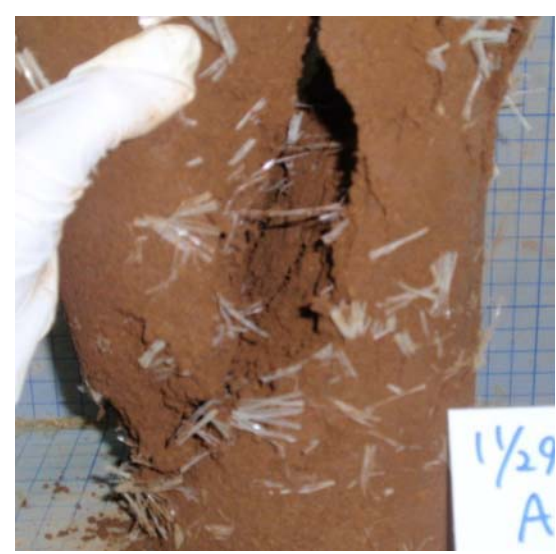

写真－3 架橋効果

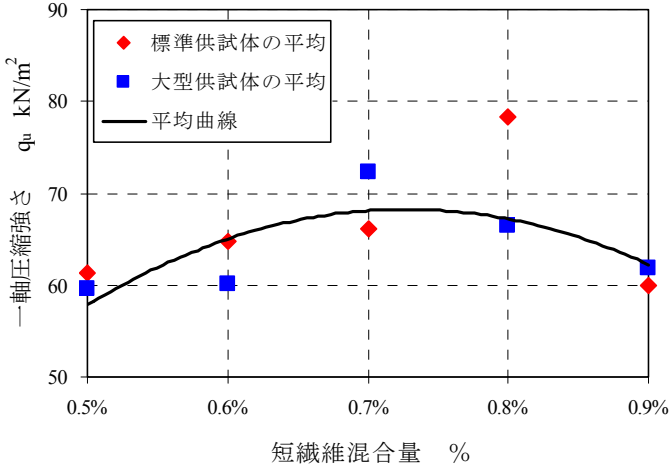

図-6 短繊維 A の最適混合量 (一軸 圧縮強度 $\mathrm{q}_{\mathrm{u}}$ )

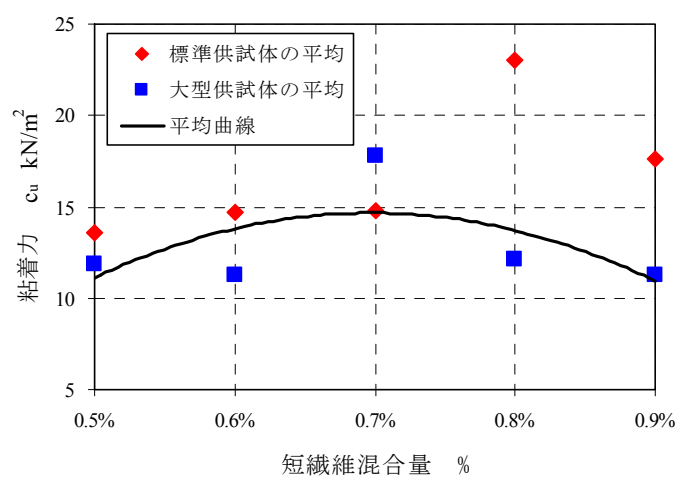

図-7 短繊維 $\mathrm{A}$ の最適混合量 (粘着力 $\mathrm{c}_{\mathrm{u}}$ )

表－4 短繊維 A の一軸圧縮試験結果

\begin{tabular}{|c|c|c|c|c|c|c|c|}
\hline \multirow{5}{*}{$\begin{array}{c}\text { 標準 } \\
5 \times 10 \mathrm{~cm}\end{array}$} & 配合条件 & A $0.5 \%$ & A $0.6 \%$ & A $0.7 \%$ & A $0.8 \%$ & A $0.9 \%$ & 短繊維なし \\
\hline & 一軸圧縮強さ $\mathrm{q}_{\mathrm{u}} \mathrm{kN} / \mathrm{m}^{2}$ & 61.3 & 64.8 & 66.1 & 78.3 & 59.9 & 49.8 \\
\hline & 粘着力 $c_{\mathrm{u}} \mathrm{kN} / \mathrm{m}^{2}$ & 13.6 & 14.7 & 14.8 & 23.0 & 17.6 & 11.7 \\
\hline & 世儿断抵抗角 $\phi_{\mathrm{u}}{ }^{\circ}$ & 42.4 & 41.6 & 42.0 & 30.0 & 29.2 & 41.8 \\
\hline & 変形係数 $\mathrm{E}_{50} \mathrm{MN} / \mathrm{m}^{2}$ & 2.42 & 2.78 & 1.82 & 4.87 & 1.98 & 5.30 \\
\hline \multirow{5}{*}{$\begin{array}{c}\text { 大型 } \\
10 \times 20 \mathrm{~cm}\end{array}$} & 配合条件 & $0.5 \%$ & A $0.6 \%$ & A $0.7 \%$ & A $0.8 \%$ & A $0.9 \%$ & 短繊維なし \\
\hline & 一軸圧縮強さ $q_{\mathrm{u}} \mathrm{kN} / \mathrm{m}^{2}$ & 59.6 & 60.1 & 72.3 & 66.5 & 61.9 & 60.2 \\
\hline & 粘着力 $c_{\mathrm{u}} \mathrm{kN} / \mathrm{m}^{2}$ & 11.9 & 11.3 & 17.8 & 12.1 & 11.2 & 17.7 \\
\hline & 世九断抵抗角 $\phi_{\mathrm{u}}{ }^{\circ}$ & 50.0 & 46.7 & 38.0 & 50.0 & 50.0 & 33.5 \\
\hline & 変形係数 $\mathrm{E}_{50} \quad \mathrm{MN} / \mathrm{m}^{2}$ & 2.33 & 1.89 & 2.74 & 2.97 & 2.06 & 3.90 \\
\hline
\end{tabular}

表一 5 短繊維 B の一軸圧縮試験結果

\begin{tabular}{|c|c|c|c|c|c|c|c|}
\hline \multirow{5}{*}{$\begin{array}{c}\text { 標隻 } \\
5 \times 10 \mathrm{~cm}\end{array}$} & 配合条件 & В $0.5 \%$ & В $0.6 \%$ & В $0.7 \%$ & B $0.8 \%$ & В $0.9 \%$ & 短繊維なし \\
\hline & 一軸圧縮強さ $\mathrm{q}_{\mathrm{u}} \mathrm{kN} / \mathrm{m}^{2}$ & 58.7 & 82.4 & 67.0 & 70.7 & 54.3 & 49.8 \\
\hline & 粘着力 $c_{u} \mathrm{kN} / \mathrm{m}^{2}$ & 13.3 & 20.5 & 16.1 & 18.2 & 13.8 & 11.7 \\
\hline & 世九断抵抗角 $\phi_{u}{ }^{\circ}$ & 42.4 & 37.2 & 38.8 & 36.0 & 36.0 & 41.8 \\
\hline & 変形保数 $\mathrm{E}_{50} \mathrm{MN} / \mathrm{m}^{2}$ & 2.94 & 4.09 & 2.10 & 3.72 & 1.67 & 5.30 \\
\hline \multirow{5}{*}{$\begin{array}{c}\text { 大型 } \\
10 \times 20 \mathrm{~cm}\end{array}$} & 配合条件 & B $0.5 \%$ & B $0.6 \%$ & B $0.7 \%$ & B $0.8 \%$ & B $0.9 \%$ & 㗐繊維なし \\
\hline & 一軸圧縮強さ $\mathrm{q}_{\mathrm{u}} \mathrm{kN} / \mathrm{m}^{2}$ & 68.2 & 65.4 & 69.3 & 58.8 & 64.8 & 60.2 \\
\hline & 粘着力 $c_{\mathrm{u}} \mathrm{kN} / \mathrm{m}^{2}$ & 15.6 & 18.0 & 16.6 & 18.6 & 14.5 & 17.7 \\
\hline & 世九断抵抗角 $\phi_{u}{ }^{\circ}$ & 41.3 & 33.3 & 40.7 & 26.7 & 43.3 & 33.5 \\
\hline & 変形係数 $\mathrm{E}_{50} \mathrm{MN} / \mathrm{m}^{2}$ & 5.13 & 2.30 & 2.74 & 2.85 & 2.89 & 3.90 \\
\hline
\end{tabular}

（2）圧密非排水三軸圧縮試験（CU 試験）

本研究では短繊維なしと短繊維 A 標準 $0.7 \%$ の配 合条件で三軸圧縮試験（CU 試験）を行った。その 最大主応力差 $\left(\sigma_{\mathrm{a}}-\sigma_{\mathrm{r}}\right)_{\text {max }}$ の結果を表一 6 に示す。

ここでは，等方応力条件のもとで圧密排水させた 後, 非排水条件で軸方向に圧縮したときの主応力差 一ひずみ曲線を求め，短繊維なしと短緎維 $\mathrm{A}$ 標準 $0.7 \%$ の供試体とで圧密過程の体積変化量と圧縮強さ の比較を行った。供試体を圧密させたときの体積変 化量 $\Delta \mathrm{V}_{\mathrm{c}}$ を表－7に示す。このとき，低拘束圧で は短繊維を混入してないものと短繊維混合補強土と 
では体積変化量に大きな差異は発現せず，拘束圧が 高くなるにつれて短繊維を混合したものの方が大き な体積変化を生じることがわかった。これは，短繊 維と土の間に存在する隙間が高セル圧により減少し, その現象が供試体全体の体積変化に影響を及ぼした と考えられる。

次に, 短繊維なしと短緎維混合補強土の主応力差 $\left(\sigma_{\mathrm{a}}-\sigma_{\mathrm{r}}\right)$ と軸ひずみ $\varepsilon$ の関係を図－8，図－9に 示す。これらの図を比較すると, セル圧 20,30 , $50,100 \mathrm{kN} / \mathrm{m}^{2}$ のいずれにも短繊維混合による補強 効果は見られるが，高セル圧では顕著な補強効果は 見られなかった。これは，供試体内に含まれる短繊 維が高セル圧によって圧縮したため短繊維と土の間 に間隙が発生して，その間隙によって供試体内の骨 格構造が変化したためと考えられる。

表ー6 CU 試験で得られた最大主応力差

\begin{tabular}{|r||r|r|}
\hline セル圧 & 短繊維なし & 短繊維A 標準 $0.7 \%$ \\
\hline 20 & 73.1 & 91.6 \\
\hline 30 & 94.1 & 112.5 \\
\hline 50 & 139.5 & 140.5 \\
\hline 100 & 176.9 & 195.2 \\
\hline
\end{tabular}

単位 : $\mathrm{kN} / \mathrm{m}^{2}$

表－7 圧密による体積変化量

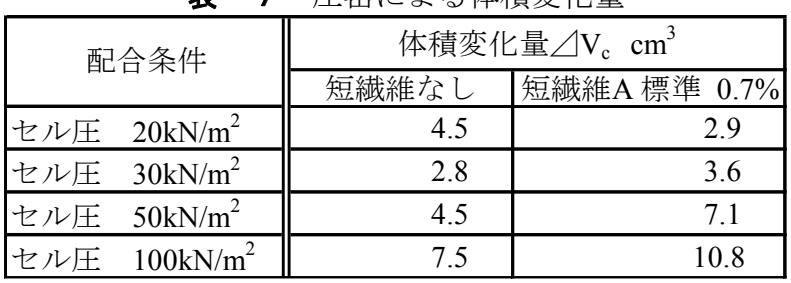

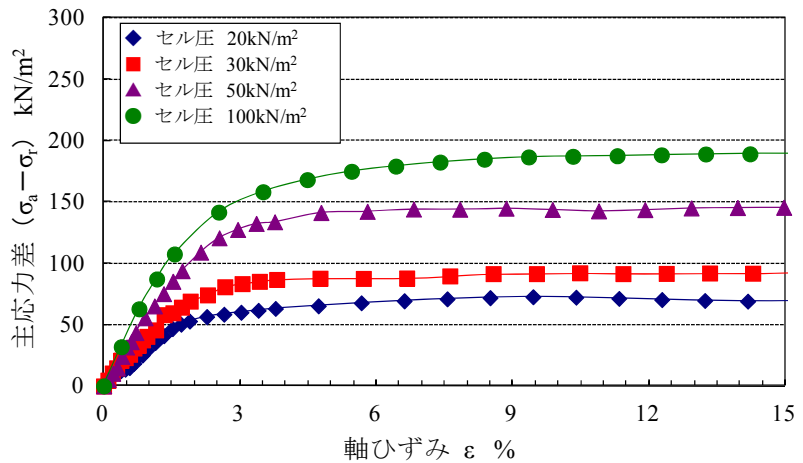

図－8 主応力差と軸ひずみの関係（短繊維なし）

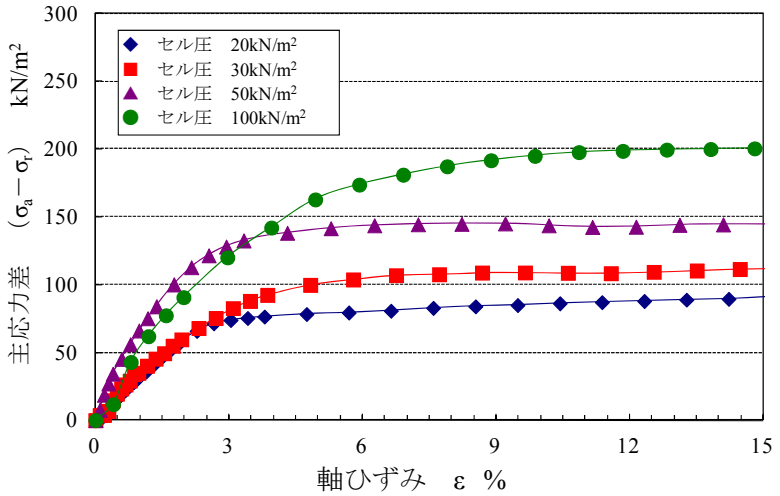

図-9 主応力差と軸ひずみの関係（短繊維 A 標準 $0.7 \%$ )

\section{6. 斜面の安定解析}

標準供試体での一軸圧縮試験と CU 試験でそれぞ れ得られた一軸圧縮強さ $\mathrm{q}_{\mathrm{u}}$ と最大主応力差 $\left(\sigma_{\mathrm{a}}-\sigma_{\mathrm{r}}\right)$ max を用いて，モールの応力円を描き，そこから全 忘力表示の強度定数を求めた結果を表 - 8 に示す。 この結果を用いて分割法による斜面の安定解析を行 い，安全率 $\mathrm{F}_{\mathrm{s}}$ を短繊維なしと短䋊維混合でそれぞ れ求め, 安定性の向上について検討した。安定解析 のモデル斜面を図－10 に示す。安定解析は，円形 すべり解析法 (簡便分割法) 6)を用い行った。この 結果，短繊維を混合することにより $\mathrm{F}_{\mathrm{S}}=2.09$, 短繊 維なし $\mathrm{F}_{\mathrm{S}}{ }^{\prime}=1.46$ となり安全率が 1.4 倍上昇し, 安定 性が向上することが確認できた。

表－8 せん断試験で得られた強度定数

\begin{tabular}{|l||r|r|}
\hline 配合条件 & 短繊維なし & 短繊維A 標準 $0.7 \%$ \\
\hline 粘着力 $\mathrm{c}_{\mathrm{u}} \mathrm{kN} / \mathrm{m}^{2}$ & 20.7 & 29.9 \\
\hline せん断抵抗角 $\phi_{\mathrm{u}}{ }^{\circ}$ & 9.2 & 7.9 \\
\hline
\end{tabular}

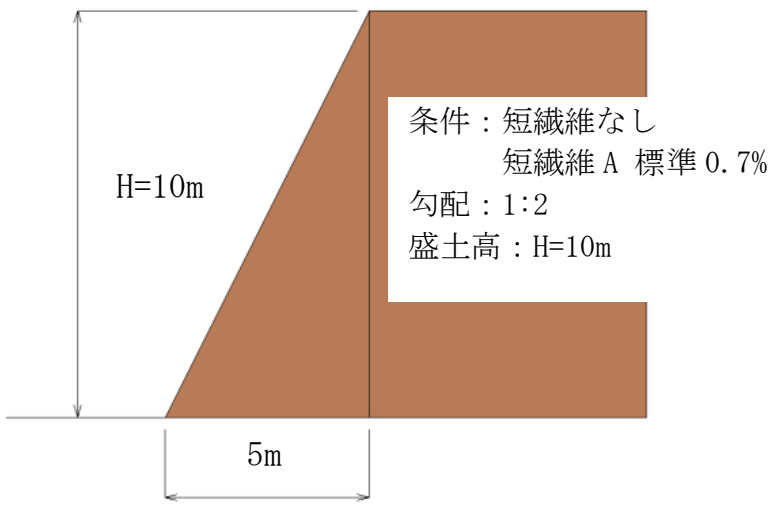

図ー 10 安定解析のためのモデル斜面 


\section{7. 結論}

本研究より得られた結果を以下に示す。

・短繊維を混合することで圧縮強度が増加し, 補強効果が期待できる。

・ 供試体寸法を大きくすることで，短繊維 B の 残留強度が顕著に見られた。

- 一軸圧縮強度 $\mathrm{q}_{\mathrm{u}}$ と粘着力 $\mathrm{c}_{\mathrm{u}}$ の観点より, 短繊 維 $\mathrm{A}$ を $0.7 \%$ 混合することが最適であることが わかった。

- 短繊維を混合することで斜面の安定解析で安 全率が増加し, 道路盛土への応用が可能である ことが確認できた。

謝辞：本研究で用いた補強材は，三菱樹脂株式会社 間昭徳氏の提供によるものである。ここに記して謝 意を表します。
参考文献

1) 補強土構造物の理論と実際, （株）鹿島出版会 p.4，1985 年 4 月

2) 国土交通省リサイクルのホームページ： http://www.mlit.go.jp/sogoseisaku/region/recycle/fuku sanbutsu/genjo/zirei.html 2005 年

3)（株）三菱樹脂：ウルトラネット資料集，2003 年.

4) 関東ローム研究グループ : 関東ロームその起原 と性状，築地書館，pp.42-203，1965 年 3 月

5) 栗橋, 田口, 岸, 三上 : PVA 短繊維を混入した $\mathrm{RC}$ 片持ち梁の静的載荷実験, 寒地土木研究所月 報 No64 2008 年 9 月

6)地盤工学数式入門編集委員会編 : 地盤工学数式 入門，（社）地盤工学会, pp.151 157，2001 年 5 月.

\section{EFFECTS OF MIXING RATIO OF REINFORCEMENT MATERIAL ON SHORTFIBER-REINFORCEMENT SOIL}

\section{Hiroki OKUYAMA, Kunio MINEGISHI and Katsuhiko MAKIUCHI}

The shortfiber admixture reinforced method is a reinforcement soil technology that makes to high value added by stirring and mixing the short fiber, and produces a more excellent ground material. Therefore, it is suitable for the having efficacy of the local surplus soil to instability.

In this study, we carried out the unconfined compression and triaxial compression tests (consolidated undrained) using Kanto loam as a sample soil, and the change in the kind and blending quantity of the shortfiber reinforcement may examine the influence that caused it for the reinforcing mechanism of the shortfiber admixture reinforced soil in the present study (CU test), and the results were considered.

KEYWORDS: reinforced soil, shortfiber, displaced soil at construction 